\title{
A CRIAÇÃO DE ESPAÇOS SOCIAIS COMO FORMA DE LUTA DAS MULHERES ARTESÃS DE ALAGOAS: A EXPERIÊNCIA DA ECONOMIA SOLIDÁRIA. ${ }^{1}$
}

\author{
Ana Maria Rita Milani ${ }^{2}$ \\ Marlene Grade ${ }^{3}$
}

\begin{abstract}
Resumo: Este artigo busca especificar como a economia solidária vem construindo novos espaços para a reprodução social dos trabalhadores no Brasil, essencialmente no estado de Alagoas, evidenciando como possibilidade a superação de uma lógica puramente utilitária que norteia a sociedade vigente. Essa trajetória, ainda que contraditória e difícil de se fazer hegemônica, pode embasar processos que conduzem a uma transformação social. Discutir essa perspectiva e evidenciar o contributo da economia solidária implica em dar-lhe o devido espaço, destacando sua importância como experimento social ao constituir práticas alternativas e possibilidades reais de organização diferenciada em um momento em que, mais uma vez, o capitalismo atravessa uma intensa crise. A metodologia utilizada neste trabalho tem como seu ponto de partida as condições reais e contraditórias dos próprios grupos. Sendo assim, a metodologia pode ser interpretada na concepção da pesquisa-ação, na qual o pesquisador deixa claro a relevância da prática e intervenção no processo de pesquisa. As organizações sociais acionaram ao longo de sua constituição instrumentos pedagógicos de gestão, de estratégias e de materiais que podem indicar elementos de um novo espaço que se contrapõe e põe em "xeque" o espaço do capital como forma de reprodução destas populações.
\end{abstract}

Palavras-chaves: Economia solidária. Espaço. Cooperação. Solidariedade.

\section{THE CREATION OF SOCIAL SPACES AS A FORM OF FIGHTING WOMEN ARTISANS OF ALAGOAS: THE EXPERIENCE OF THE SOLIDARY ECONOMY}

\begin{abstract}
This article seeks to specify how the solidarity economy has been building new spaces for the social reproduction of workers in Brazil, essentially in the state of Alagoas, showing as a possibility the overcoming of a purely utilitarian logic that guides the current society. This trajectory, although contradictory and difficult to become hegemonic, can support processes that lead to a social transformation. Discussing this perspective and highlighting the contribution of solidarity economy implies giving it due space, highlighting its importance as a social experiment by establishing alternative practices and real possibilities of differentiated organization at a time when, once again, capitalism goes through an intense crisis. The methodology used in this work has as its starting point the real
\end{abstract}

\footnotetext{
${ }^{1}$ Agradecimentos ao CNPq pelo apoio financeiro do projeto de pesquisa. Agradecemos a todos os bolsistas e, em especial, a Rejane Soares de Oliveira, Layne Mariela de Souza Santos Cordeiro e Raíssa Aryadne de Andrade Lima pela elaboração dos gráficos.

2 Doutora em Economia pela UFRGS. Professora Adjunta da Faculdade de Economia, Administração e Contabilidade da UFAL. Coordenadora do Curso de Mestrado em Economia CMEA-UFAL. Email: anamilani16@hotmail.com

3 Doutora em Geografia pela UFSC. Professora do Centro de Ciências Agrárias da UFSC. Email: melgrade@gmail.com
} 
and contradictory conditions of the groups themselves. Thus, the methodology can be interpreted in the conception of action research, in which the researcher makes clear the relevance of practice and intervention in the research process. Throughout their constitution, social organizations have introduced pedagogical instruments of management, strategies and materials that can indicate elements of a new space that opposes and puts the capital space as a way of reproducing these populations.

Keywords: Solidarity economy. Space. Cooperation. Solidarity.

\section{LA CREACIÓN DE ESPACIOS SOCIALES COMO FORMA DE LUCHA DE LAS MUJERES ARTESANAS DE ALAGOAS: LA EXPERIENCIA DE LA ECONOMÍA SOLIDARIA}

Resumen: Este artículo busca especificar cómo la economía solidaria viene construyendo nuevos espacios para la reproducción social de los trabajadores en Brasil, esencialmente en el estado de Alagoas, evidenciando como posibilidad la superación de una lógica puramente utilitaria que orienta la sociedad vigente. Esta trayectoria, aunque contradictoria y difícil de hacerse hegemónica, puede dar soporte a procesos que conducen a una transformación social. Discutir esa perspectiva y evidenciar la contribución de la economía solidaria implica darle el debido espacio, destacando su importancia como experimento social al constituir prácticas alternativas y posibilidades reales de organización diferenciada en un momento en que, una vez más, el capitalismo atraviesa una intensa crisis. La metodología utilizada en este trabajo tiene como punto de partida las condiciones reales y contradictorias de los propios grupos. Así, la metodología puede ser interpretada en la concepçión de la pesquisa-acción, en la cual el investigador deja claro la importancia de la práctica e intervención en el proceso de investigación. Las organizaciones sociales accionaron a lo largo de su constitución instrumentos pedagógicos, de gestión, de estrategias y de materiales que pueden indicar elementos de un nuevo espacio que se contrapone y pone en "jaque" el espacio del capital como forma de reproducción de estas poblaciones.

Palabras claves: Economía solidaria. Espacio. Cooperación. Solidaridad.

\section{Introdução}

Utopia consta no dicionário de filosofia como sendo a um só tempo, lugar nenhum e lugar feliz (ABBAGANANO, 2000). Para Eduardo Galeano, a utopia assume como significado "um salto para o futuro carregado de memória", para Vitor Hugo, como sendo "a verdade matutina". Também se poderia somar a essas idealizações o Éden, uma utopia do paraíso.

Entretanto, a despeito de idealizações, a humanidade caminha por experimentos reais, tendo por base as condições dadas, Nesse sentido, o que buscamos neste artigo é a caracterização dos elementos produzidos pela sociedade capitalista e que se constituem em 
pré-condições materiais e sociais para uma sociedade superior à burguesa. Significa apreender qual a questão do nosso tempo? Por meio de uma formulação teórica, apresentamos a possibilidade histórica engendrada como virtuosidade do mundo burguês, o que neste artigo toma a forma da cooperação entre os homens trabalhadores, sua unidade para reproduzirem-se como seres existentes. Assim, este artigo tem como objetivo estudar os elementos produzidos nos empreendimentos econômicos solidários da cadeia produtiva do artesanto no estado de Alagoas que emergem como possibilidade de constituição de uma nova práxis social.

Para pensar essas organizações sociais advindas da classe trabalhadora utilizamos os conceitos da economia solidária, como solidariedade e cooperação, para neles caracterizar o que emerge como nova possibilidade de participação e de inserção social. Levantaremos, também, alguns elementos resgatados na pesquisa que está em andamento na Universidade Federal de Alagoas. Essa pesquisa intitulada: "Incubação de Empreendimentos Econômicos Solidários (EES) no estado de Alagoas: fortalecimento da autogestão e da comercialização da Cadeia produtiva de artesanato", tem como objetivo a construção de uma rede de comercialização. Esses elementos encontram-se na organicidade das mulheres artesãs, caracterizadas como população em vulnerabilidade, que buscam a construção de caminhos possíveis dentro dessa materialidade social posta.

A metodologia pressupõe a interação teórico-prática entre os participantes de modo a articular as ações e reflexões a partir das condições dadas. Trata-se da condução em que os diversos parceiros interagem a partir e nas práticas em que estão envolvidos. Ou seja, o ponto de partida é sempre as condições reais e contraditórias dos próprios grupos. Sendo assim, a metodologia pode ser interpretada na concepção da pesquisa-ação, na qual o pesquisador deixa claro a relevância da prática e intervenção no processo de investigação. Consiste no acompanhamento sistemático de 25 grupos de economia solidária em seis regiões do estado de Alagoas. Esses grupos, ao todo, contemplam mais de 250 artesãos.

Além desta introdução, a primeira seção abordará a construção teórica do que vem se manifestando como economia solidária e cooperativismo solidário em alguns autores que trabalham sobre esta temática e em como esta forma de organização social emerge, ainda que contraditoriamente em um espaço de superação da organização vigente. Apresentam-se como processo contraditório do capital que mostra a necessidade/possibilidade de superação 
do modo de produção capitalista, neste sentido novos espaços vêm sendo construídos pela dinâmica organizativa da classe trabalhadora na luta pela sua reprodução social. A segunda seção, ilustrar-se-á a empiria das mulheres artesãs do estado de Alagoas que encontram na solidariedade o espaço de reprodução fora dos padrões que estabelece o capital. Por último, as considerações finais.

\section{Economia solidária: espaço que pode conduzir a uma transformação social?}

As cooperativas se constituem como instrumentos coletivos de desenvolvimento econômico e fortalecimento comunitário. Nelas a cooperação e a solidariedade são à base de sua organização. Podem definir-se como organizações que exprimem as lutas dos trabalhadores contra a exploração, em que o homem, o ser humano, passa a ser o centro da produção e organização e não o lucro. Tem por base o trabalho e a distribuição equitativa dos excedentes entre os trabalhadores, havendo redistribuição solidária da renda ou decisão coletiva sobre sua utilização. Nas cooperativas solidárias, a socialização dos recursos e a prática de equidade são fundamentais. A gestão coletiva do bem comum, os laços mais horizontais, democráticos e igualitários também são características basilares das cooperativas solidárias. Embora a eficiência econômica seja necessária, pratica-se a autogestão, que pauta o desenvolvimento humano como eixo norteador da produção e da organização do trabalho. Seus princípios são a propriedade coletiva ou associada do capital, não havendo separação entre trabalho e meios de produção, e o direto à liberdade individual.

O caminho que, ao longo da história da classe trabalhadora, apresentou-se como possibilidade desta se reproduzir individual e socialmente, à medida que se confronta com limites reais para manter-se vivente, encontra-se no cooperativismo e na solidariedade, estes são seus elementos constituintes. Vários são os exemplos de experimentos históricos que indicam essa construção apontados por alguns autores e outros que ousaram implementar ações efetivas, tais como: Charles Fourier (1772-1837), Robert Owen (1770-1858), Willian King (1786-1865) Pierre Joseph Proudhon (1809-1865); Louis Blanc (1812-1882). O mais importante deles como construtor de experimentos reais foi Robert Owen, que deu origem ao movimento owenista fundando diversas cooperativas administradas coletivamente, e Proudhon, que elaborou teoricamente um completo sistema de organização para uma sociedade autogestionária. Outros exemplos desta fase inicial são as Aldeias Cooperativas também de Robert Owen, que resultaram na criação das cooperativas owenistas como a 
London Co-operative Society que reunia um grupo de jornalistas e gráficos em Londres, em 1821 e 1822 publicaram o The Economist, o primeiro jornal cooperativo; e os Falanstérios de Charles Fourier (exemplo: colônia de Sai no Norte do estado de Santa Catarina).

O cooperativismo surgiu, assim, na Europa Ocidental quase que simultaneamente com a revolução industrial como uma organização que exprime as lutas dos trabalhadores contra as condições de exploração vivenciadas neste período. Emerge como um ideário filósofo e empírico (uma práxis social) do homem como ponto central ao redor do qual gravita a organização produtiva. Tem como base o trabalho e a distribuição equitativa do excedente produtivo entre os trabalhadores. Sua ênfase está no aprimoramento e desenvolvimento humanos em suas dimensões sociais e culturais.

No Brasil diversas experiências de cooperativismo emergem embasados por estes ideais do cooperativismo europeu. Entretanto, foi o Governo Médice que criou o Decreto-Lei n. 5.764 de dezembro de 1971 que regulou seu funcionamento e constituiu a OCB (Organização das Cooperativas Brasileiras), órgão que representa nacionalmente estas organizações. Em meados do Governo Fernando Collor de Melo, para além desta esfera que compõe o cooperativismo tradicional, começa a aparecer, como um resgate dos ideários solidários do cooperativismo europeu, um outro caráter do cooperativismo no Brasil, órgãos como o FAT (Fundo de Amparo ao Trabalhador) e os PROGER (Programa de Geração de Emprego e Renda) urbano e rural, incentivaram tais experiências e acentuaram seu caráter autogestionário e popular. Emergem as diversas formas cooperativas, como as de produção, de comercialização, de trabalho e também a construção de redes de economia solidária que buscam construir intercâmbios entre estes experimentos que toma características que se voltam para o que se convencionou chamar de economia solidária (CULT, 2018).

De tal forma que no Brasil a economia solidária foi a marca que permeou o final do século XX teórica e empiricamente que sistematiza a busca por uma sociedade igualitária. Caracteriza a fase em que os movimentos sociais, o de fábricas recuperadas e essencialmente o MST debruçam-se para se organizar produtiva e socialmente. Ainda sob o termo economia popular, foi em 1994, que as primeiras publicações aparecem academicamente. Em fins da década de 1990 é que o termo economia solidária passa a ser difundido e amplamente utilizado, ao mesmo tempo em que instituições como associações, sindicatos, incubadoras universitárias, etc. a promovem, buscando legitimá-la, como um espaço de novas possibilidades de organização da vida e do trabalho. Nela, pela autogestão, a solidariedade 
passa a ser o nexo social, através do qual se constituem as organizações produtivas, quer sejam associações ou cooperativas solidárias.

O termo economia solidária consolida-se à medida que as iniciativas econômicas despontam e são reconhecidas por sua natureza cooperativa, solidária e autogestionária. Abrange modalidades diversas de organização como as formas informais de geração de renda, associações de produtores e consumidores, comunidades produtivas autóctones. Todavia seu modelo mais bem acabado são as cooperativas de produção, de prestação de serviços, de comercialização e de crédito.

A primazia que esses empreendimentos concedem à solidariedade manifesta-se na socialização dos recursos produtivos e na adoção de equidade (GUERRA, 2002; PINTO, 2006; GAIGER, 2013; GAIGER, 2004). Para estes autores a solidariedade estimula sistemas mais amplos de reciprocidade, nos quais as vivências concretas e a gestão do bem comum conferem um novo valor à noção de justiça e de interesse público. Essa trajetória ainda que difícil se fazer hegemônica, pode embasar processos que conduzem a uma transformação social.

Sua emergência no Brasil é interpretada como uma reação às crises cíclicas do capitalismo, que atinge o país na década de 1990 e à desregulamentação do Estado na economia ${ }^{4}$. A essa combinação: redução da presença do Estado; escassez de financiamento público para as demandas sociais; revolução tecnológica provocando profundas transformações no mercado de trabalho, soma-se a crise que eleva o número de alijados do sistema produtivo. Sem emprego e sem condições de sobrevivência, esses indivíduos passam a se organizar em grupos autossustentáveis, solidários, para o auxílio mútuo.

Neste "vazio" a economia solidária aparece como "modo de produção intersticial", como apresenta a compreensão de Paul Singer, preenchendo espaços econômicos e lacunas sociais que o capitalismo havia produzido. Exemplo típico são as empresas recuperadas e autogeridas que começam a emergir neste período, introduzindo elementos de democracia e igualdade, assim como as cooperativas e associações constituídas pelo MST em seus assentamentos (GAIGER, 2013; CULT, 2018).

As cooperativas de economia solidária constituem o modelo para o qual converge grande parte dos programas de promoção das iniciativas de Microcrédito, embora nele, como

\footnotetext{
${ }^{4}$ Nesta fase inicial a Teologia da Libertação, movimento da Igreja Católica que se constituiu em Comunidades Eclesiais de Base (CEBs) auxilia e promove substantivamente essas organizações.
} 
na própria economia solidária, se concentrem controvérsias agudas sobre a natureza e o valor social de tais experiências. Gaiger (2013) observa que o surgimento de cooperativas populares dentro da economia solidária, revitaliza a discussão sobre o cooperativismo. Acentua que o cooperativismo nasceu no mesmo berço das lutas sindicais e políticopartidárias que formou o movimento operário. Tanto o sindicalismo, o cooperativismo e as lutas político partidárias não conduziram a epílogos revolucionários, a passagens para o socialismo; não escaparam a desvirtuamentos e instrumentalizações, mas nenhuma tampouco deixou de afetar radicalmente o capitalismo e alimentar utopias e lutas contra a iniquidade e a desumanização, acresce o autor (idem).

Nesse sentido tanto o cooperativismo solidário (forma mais bem acabada de economia solidária) como a própria economia solidária em pleno século XXI, explica Gaiger (2013), reeditam a estratégia histórica dos trabalhadores. Esta estratégia permite aludir a um paradigma cooperativo, cuja longevidade explica-se por sua consistência utópica, assim como seu pragmatismo e abertura diante das constantes mudanças em que prosperou (NAMORADO, 2007). O cooperativismo dos trabalhadores adentra o século XXI conhecedor de reveses, de estagnação, de distorções, mas ainda assim sua história exprime a recursa dos trabalhadores de viverem encerrados em uma lógica social fundada no utilitarismo e na renúncia ao cultivo de vínculos sociais (GAIGER, 2013).

Chanial e Laville (2009) explicam que somente uma teorização que considere a solidariedade como princípio de ações coletivas, diverso do agir instrumental, tem condições de compreender a originalidade que se expressa nestas práticas coletivas. Para Grade (2012) a solidariedade é nexo social que permite aglutinar ao redor de si os trabalhadores, para além do salário e do lucro. A solidariedade remete à liberdade e busca de condições intersubjetivas da integridade pessoal e ultrapassa a lógica do interesse.

Os estudos no Brasil sobre esta temática convergem sobre o aparecimento e a revitalização de tais experiências cooperativas. Seus fios históricos remontam às mudanças no padrão de acumulação capitalista no fim do século XX, que envolveram a reconfiguração dos mercados, e a reestruturação econômica a partir das cadeias produtivas; assim como a crise que atingiu o trabalho assalariado e que gerou grandes ondas de desemprego e de insegurança econômica, compelindo os trabalhadores em buscas de alternativas para a sua reprodução.

Singer é o autor que pauta consideravelmente estes estudos, uma vez que para ele, a 
economia solidária é reinventada. Ela surge como modo de produção no interior da sociedade capitalista há cerca de 200 anos, com o amadurecimento do capitalismo industrial, principalmente na Europa, nos experimentos cooperativistas dos "socialistas utópicos", como Roberto Owen, Charles Fourier, Joseph Proudhon. De forma que, para ele, a economia solidária é um modo de produção que se constitui ao lado do modo de produção capitalista, da pequena produção de mercadorias, da produção estatal, da produção privada sem fins de lucro, Singer (2002a) aponta que todos esses modos de produção compõem a formação social capitalista que só é capitalista porque o capitalismo é o maior modo de produção e molda a superestrutura legal e institucional à sua lógica. Seu principal protótipo é a cooperativa solidária.

Para Singer, a economia solidária deverá aproveitar-se do desenvolvimento das forças produtivas; relacionar-se com o mercado capitalista, não privilegiar, nem buscar o isolamento; ela não prescinde inteiramente do Estado, mas deve buscar a sua autonomia; ter como base a história do movimento anticapitalista. A cada mudança institucional capitalista ocorre uma reação às contradições do capitalismo posto a cabo pela classe trabalhadora. Nesse sentido a grande questão para Singer é buscar saber se a economia solidária é somente uma reação à crise que se instalou no capitalismo a partir da década de 1970, ou se nela há alguma consciência efetivamente nova que aponte para a afirmação de um novo modo de produção solidário.

Debates constantes travam-se atualmente entre lideranças, militantes e acadêmicos acerca do papel e dos rumos da economia solidária e do cooperativismo solidário. Emergem como saídas ao desemprego? Após este período de existência admite-se que estas experiências encerram dimensões propositivas com reflexos nas políticas públicas e fortalecimentos dos movimentos sociais. Namorado (2007) corrobora que elas se constituem tanto em instrumentos de compensação e de equilíbrio, como em forma de resistência à logica dominante e como espaço propulsor de alternatividade.

O Mapeamento Nacional de Economia Solidária, em 2007, registrou mais de 2.100 cooperativas designadas de populares ou de economia solidária. Gaiger (2013) explica que em sua maior parte estas cooperativas recenseadas haviam iniciado suas atividades quinze anos antes do Mapeamento. Culti (2018) assinala que, em grande medida, foram motivadas pela convicção de que esse formato é o modelo mais bem acabado de autogestão e de solidariedade econômica. Elas têm se alinhado em favor de um novo modelo de 
cooperativismo, ao questionarem o perfil político e os principais impasses que o cooperativismo de base empresarial tem adotado no país, relacionados, sobretudo, entre os princípios doutrinários e o seu desenvolvimento histórico (GAIGER, 2013).

Exemplos deste formato de cooperativismo solidário podem ser destacados nas cooperativas constituídas pelo Movimento dos trabalhadores Sem Terra (MST) cujo objetivo tem sido o de propugnar um novo cooperativismo. Nestes experimentos acentua-se o caráter solidário do cooperativismo, como obra de trabalhadores cooperados, autogestionários, que busca suplantar o cooperativismo tradicional. Também verificam-se nas organizações urbanas que emergem nas periferias urbanas como formas de superação da exclusão e da marginalidade das populações que ali habitam, é o que vem ocorrendo em Alagoas, no estudo situado ao longo deste artigo.

Discutir essa perspectiva e debate-la evidenciando o contributo da economia solidária no Brasil implica em dar-lhe o devido espaço, destacando sua importância como experimento social ao constituir práticas alternativas e possibilidades reais de organização diferenciada em um momento em que, mais uma vez, o capitalismo atravessa uma intensa crise, assinalando seu esgotamento como modo de produção para uma camada significativa da população que não consegue reproduzir sua vida nestas condições.

Neste sentido a economia solidária pode estar assinalando a construção de novo espaço de transformação social em que a lógica utilitarista passa a ser restrita e novas formas de relações sociais se constituem, como a solidariedade, a cooperação, a autogestão. Estes experimentos sociais ao longo dos anos de sua constituição têm somado uma competência que merece ser levantada e sistematizada no sentido de evidenciar o que pode ser entendido como uma nova sociabilidade que aponta um caminho para a transformação social. Essas organizações sociais acionaram ao longo de sua constituição instrumentos pedagógicos, de gestão, de estratégias e de materiais que pode indicar elementos de um novo espaço que se contrapõe e põe em xeque o espaço do capital como forma de reprodução destas populações.

O esforço desta pesquisa tem sido significativo no sentido de trazer à luz formas que elucidem e visibilizem estes experimentos sociais e constituam-se em padrões de referência que permitam exprimir sua lógica própria e que possam indicar uma lógica de emancipação social e econômica, impulsionando o rompimento com a subalternidade que marcam sua trajetória histórica. Trata-se de um significativo desafio: romper com situações de tutela, consolidar-se econômica e socialmente dentro de uma práxis cooperativa e solidária. São 
estes os desafios que norteiam este trabalho.

Em comum os diversos autores reforçam que a cooperação, a solidariedade são elementos capazes de converter-se no motor de uma nova racionalidade econômica. Acentuam que as pesquisas empíricas assinalam que a cooperação na gestão e no trabalho, não se contrapõe à eficiência, pelo contrário, atua como vetor de racionalização do processo produtivo, com efeitos tangíveis e vantagens reais. O trabalho cooperativo age em favor dos produtores e confere uma amplitude maior e mais ampla da conotação da eficiência econômica, vinculada à qualidade de vida e a satisfação de objetivos culturais e ético-morais.

Pesquisas empíricas (dados levantados pelo SENAES, 2007) revelam que o maior interesse e motivação dos associados, o "emprego" (acordo mútuo), da maior capacidade de trabalho possível, a divisão dos benefícios pelo aporte de trabalho, aparecem como fatos relacionados à cooperação, no sentido de buscar um maior rendimento do trabalho associado. Nas cooperativas geridas autogestionariamente, isto é nas cooperativas solidárias, os autores apontam que há uma reconciliação entre o trabalhador e as forças produtivas que ele detém e utiliza, não se encontram separadas do produto de seu trabalho e o trabalhador recupera as condições necessárias, mesmo se ainda insuficientes, para uma experiência integral com a vida laboral e adquirindo, assim, um novo patamar de satisfação não apenas do ponto de vista material ou monetário. Ou seja, nestes espaços o trabalhador emprega o capital, não é empregado por ele (GAIGER, 2013, NAMORADO 2007, CULT 2018, GRADE, 2006) .

Nos empreendimentos solidários (essencialmente as cooperativas autogestionárias ou solidárias) uma das características é a eliminação do excedente apropriado para fins privados. Sua destinação nestes espaços fica a cargo dos trabalhadores, ou somando-se à remuneração ou reinvestida na empresa. A supressão do assalariamento, do antagonismo entre capital e trabalho, desonera a empresa uma vez que diminui os custos com controles, supervisão e estímulos à fidelidade e eficiência para a adesão dos trabalhadores à empresa capitalista, sempre que situações críticas evidenciam as contradições de classe. O interesse dos trabalhadores em conferir sucesso as suas organizações leva à eliminação de desperdícios e tempos ociosos, derivam da natureza associada e cooperativa do trabalho, lhes conferindo uma racionalidade própria, que pode tornar-se superior às empresas capitalistas (DEFOURNY, 1988, GAIGER, 2004). Entretanto, para assegurar sua reprodução os empreendimentos solidários precisam lidar adaptativamente com a hegemonia do capitalismo e sua própria racionalidade produtiva. 
Importa observar nos desdobramentos futuros da economia solidária, se se trata de apenas uma nova prática, a da inserção no mundo do trabalho ou se, nestes experimentos gera-se uma nova consciência que poderá provocar sucessivamente novas mudanças nas práticas. O papel da economia solidária, a ser inquirido, é o de que a autogestão não é inferior à gestão capitalista para o desenvolvimento das forças produtivas (SINGER, 2002) por dispor de vantagens comparativas derivadas de sua forma social específica de produção.

\section{Construindo novos espaços: a luta das mulheres artesãs no estado de Alagoas}

Para apreender os experimentos reais que encontram nas formas pretéritas do trabalho a forma de reprodução, apresentaremos as especificidades do artesanato alagoano por regiões geográficas como expressão do lugar e espaço. O estado de Alagoas possui três grandes mesorregiões: a) Mesorregião do Agreste Alagoano, b) Mesorregião do Leste Alagoano e c) Mesorregião do Sertão Alagoano. Entretanto, o estado é dividido em trece microrregiões que são as seguintes: 1) Microrregião de Arapiraca, 2) Microrregião de Palmeira dos Índios, 3) Microrregião de Traipú, 4) Microrregião do Litoral Norte, 5) Microrregião de Maceió, 6) Microrregião da Mata Alagoana, 7) Microrregião de Penedo, 8) Microrregião de São Miguel dos Campos, 9) Microrregião Serrana dos Quilombos, 10) Microrregião Alagoana do Sertão do São Francisco, 11) Microrregião de Batalha, 12) Microrregião da Santana de Ipanema e 13) Microrregião do Sertão Alagoano (ANEXO - Figura 1).

Começaremos a analisar os empreendimentos econômicos solidários que através da criatividade de artistas populares que encontram na cooperação a forma de reprodução de suas vidas, gerando trabalho e renda. Esses experimentos reais foram encontrados nos seguintes regiões: 1) Microrregião de Maceió; 2) Microrregião da Mata Alagoana, 3) Microrregião de Palmeira dos Índios, 4) Microrregião da Serrana do Sertão Alagoano, e 5) Microrregião da Serrana dos Quilombos, e 6) Microrregião Alagoana do Sertão do São Francisco. A continuação, detalharemos esses experimentos por cada microrregião.

\section{Microrregião de Maceió}


A Microrregião de Maceió abrange 10 municípios do estado de Alagoas que possui como base de atividade econômica a agroindústria, a pesca e o turismo. Nessa microrregião encontram-se 17 EES com 184 sócios ativos artesãos. Esses EES estão localizados em três municípios da seguinte forma: $71 \%$ de Maceió, capital do estado; $21 \%$ do município histórico de Marechal Deodoro e 9\% de Rio Largo. Essa microrregião possui o litoral com as mais belas praias turísticas de todo o Nordeste do Brasil, na qual encontra-se a cidade de Marechal Deodoro que foi tombada por sua riqueza histórica e patrimônio nacional em 2006.

Conhecida nacionalmente por ter sido o berço de um dos nomes mais importantes da política nacional também é famosa por suas artesãs, rendeiras que produzem uma das mais belas peças artesanais de todo o Brasil, o Filé (Renda de origem portuguesa, onde do tear saem peças como colchas e toalhas), sendo também exportado para o exterior. A produção do bordado Filé é herança da colonização portuguesa, na região do Complexo Estuário Lagunar Mundaú-Manguaba (CELMM), que inclui uma parte do Município de Maceió e Marechal Deodoro, possivelmente incluído na educação fornecida nas escolas cristãs católicas da época. O Filé consiste em um complexo bordado sobre uma rede de fios, atualmente foi tombado como patrimônio imaterial do Estado de Alagoas (IBORDAL, 2017).

Além do filé, os grupos tem produzido bordado crochê, ponto de cruz e material reciclado pet. Sendo alguns os produtos fantoches, material para reprodução de histórias, bolsas, tiaras, roupas, porta-joias e pesos de porta. Através de seu trabalho, produzem peças que resgatam o patrimônio cultural do Estado de Alagoas e do Nordeste, retratando figuras marcantes como Lampião, Maria Bonita, Bumba meu boi, plantas típicas e o Chapéu do Guerreiro Alagoano. Acreditam que através da economia solidária é possível fortalecer o grupo e mudar a realidade melhorando o seu bem-estar, declaram: "Economia solidária não vê o lucro, vê o bem-estar das pessoas. É sempre o nós e não o eu”. 


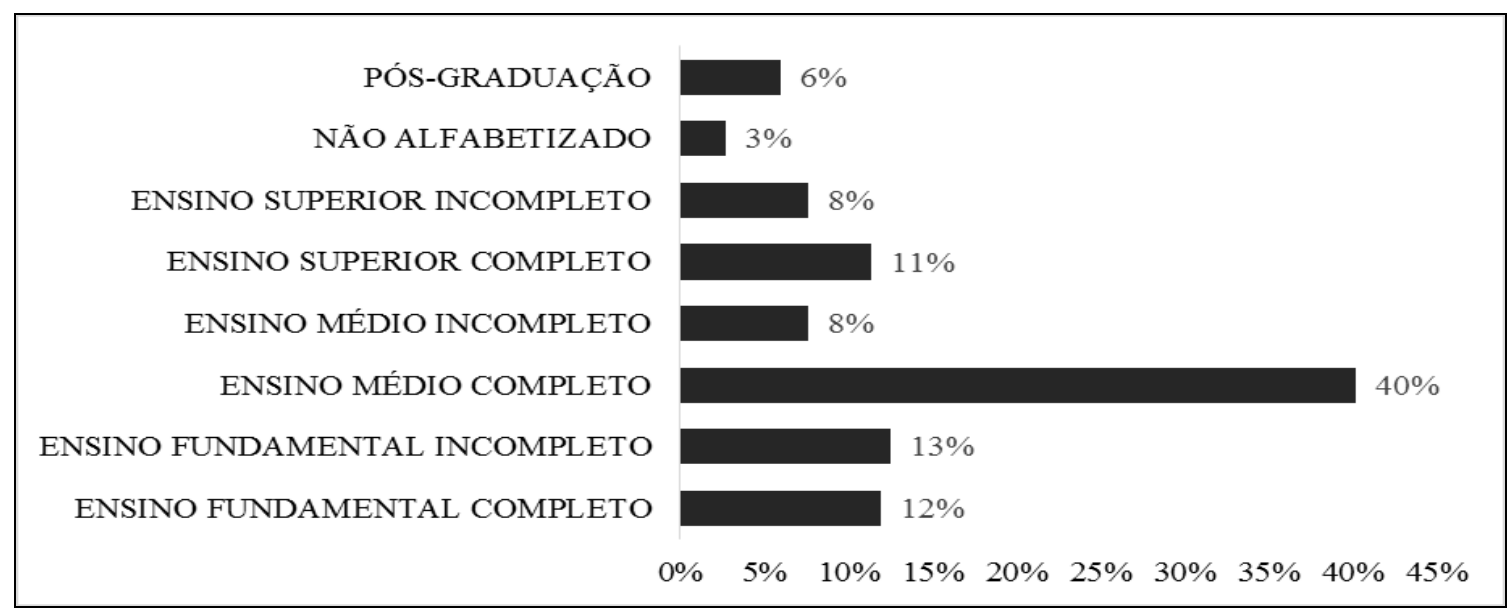

Fonte: elaborado pelo autores.

Em relação ao nível de escolaridade dos sócios, o Gráfico № 1 mostra que apenas $6 \%$ conseguiram chegar a pós-graduação, $11 \%$ tem ensino superior completo, $40 \%$ tem ensino médio completo, $12 \%$ tem ensino fundamental completo e $3 \%$ não chegaram a ser alfabetizados.

\section{Gráfico Nº 2 - Nível de Renda dos Sócios dos EES}



Fonte: elaborado pelo autores.

A renda mensal obtida pelos sócios, individualmente, a maioria não ultrapassa três salários mínimos (SM), 24\% recebem até um SM, 20\% deles recebem de um a dois SM, 13\% tem renda mensal entre dois e três SM e 37\% optaram por não informar o nível de renda recebido. Desses $11 \%$ recebem auxilio do bolsa família, enquanto $89 \%$ alegam não que não o recebem, como mostra o Gráfico $\mathrm{N}^{\circ} 2$. 
A principal dificuldade encontrada pelos artesãos é a comercialização de seus produtos, relatam que não existem espaços de comercialização para o artesanato produzido no estado e que há a presença de atravessadores, que revendem os produtos e se beneficiam dessa situação. Assim, salientam no seu relato: "Espaço de comercialização para o turista comprar do artesão e não do atravessador, não existe em Alagoas”. Entretanto sentem que a economia solidária na região está enfraquecida e o seu trabalho não é devidamente reconhecido, sendo muitas vezes atropelados por atravessadores e pessoas que não produzem artesanato e passam na frente dos produtores, relatam: "Eu faço crochê a 50 anos, aprendi com 8 anos o que você quiser eu digo, um colega foi lá com peças de crochê e o coordenador achando lindo e maravilhoso e eu comecei a perguntar e ele disse que não se preocupa com nome de linha, como um artesão não se preocupa com o material de trabalho? Perguntei, perguntei e ele não respondia nada. Então soube, esse não faz".

\section{Microrregião Mata Alagoana}

A microrregião da Mata Alagoana está formada por 15 municípios atividade econômica baseada no setor sucroalcóoleiro. No município de Atalaia encontramos dois empreendimentos econômicos solidários (EES), sendo eles: O grupo Artemix com 6 sócios (54,55\%), Associação Fibra e Arte (Fibrart) com 5 sócios (45,45\%) ou seja, nesta microrregião temos 11 sócios ao todo. O primeiro produz peças a partir da fibra de bananeira, como jarros, porta-joias e embalagens; o segundo utiliza o bordado crochê na produção de blusas e bolsas, e pinturas em tecido.

\section{Gráfico N³ - Porcentagem de sócios por Empreendimentos Econômicos Solidários}

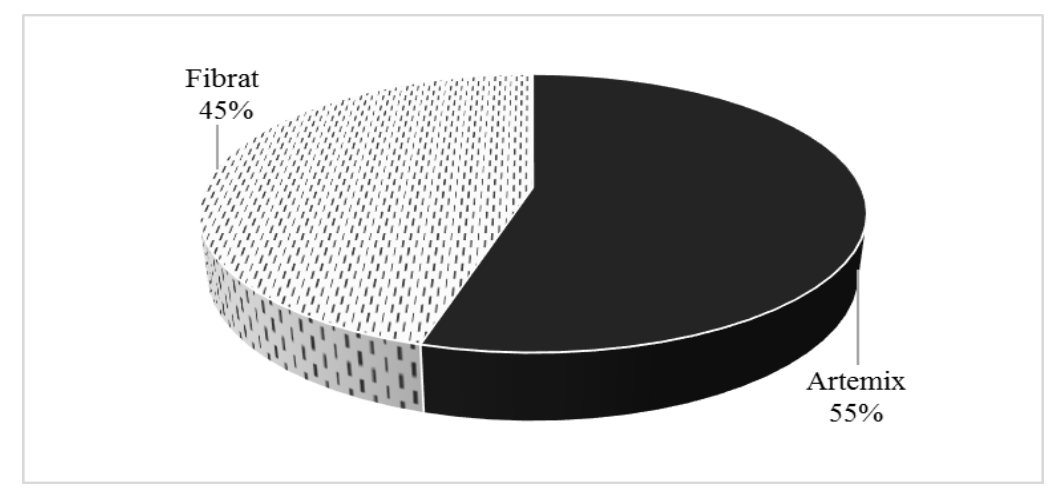

Fonte: elaborado pelo autores. 
Os empreendimentos contem em sua formação todos os sócios do sexo feminino, que buscam complementar a renda doméstica através do artesanato, ter uma ocupação além dos afazeres de casa e transmitir os sentimentos através da arte, deixando em alguns casos a depressão de lado. Sendo $93 \%$ do sexo feminino e somente $7 \%$ do sexo masculino. Analisando o perfil dos artesãos da região, têm-se que $91 \%$ dos sócios tem o artesanato como profissão principal, já 30\% possuem outros meios de renda, como a aposentadoria ou outras profissões como principais, sendo algumas delas: recepcionista, pintor, costureira.

\section{Gráfico Nº 4 - Principal profissão dos sócios da Microrregião da Mata Alagoana}

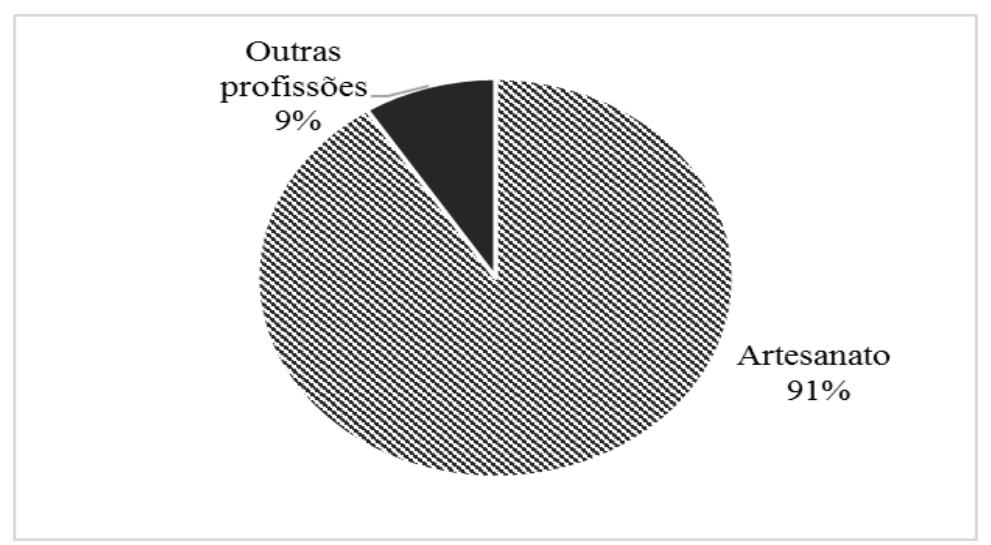

Fonte: elaborado pelo autores.

Com relação a renda mensal obtida pelos sócios, individualmente, 55\% recebem até um salário mínimo (SM), 27\% deles recebem de um a dois SM e 18\% optaram por não informar o nível de renda recebido. Desses $33 \%$ recebem auxilio do bolsa família, enquanto $67 \%$ alegam não que não recebem o auxílio.

Com o trabalho em grupo esses artesãos tentam superar as dificuldades de comercialização e do trabalho antes feito individualmente, entretanto encontram na economia solidária uma missão de vida, adotando os princípios para a vida cotidiana e criam vínculos familiares entre os sócios, declaram: "Minha missão não é individual, nasci dentro de uma família que já viviam dentro da economia solidária, mesmo sem saber o que é força e união, como dessedente não posso sair da missão." 


\subsection{Microrregião de Palmeira dos Índios}

Na região do Agreste Alagoano, no município de Palmeira dos Índios está localizada a Associação Mulheres Indígenas, que faz parte da Aldeia indígena Mãe Serra da Capela, Xucuru-Kariri, que tem cerca de 45 índios dentre eles 30 são mulheres e 15 homens.

$\mathrm{Na}$ comunidade existem casas humildes e escola para as crianças. Além disso, dada a sua localidade, os índios cultivam frutas, verduras e outros alimentos que usam como parte de seu sustento. A aldeia fica em uma região de difícil acesso, na zona rural da cidade de Palmeira dos índios, para ingressar é necessário subir uma íngreme ladeira, os moradores para se locomover necessitam utilizar moto táxis que passam no local. Em épocas de chuva não tem como chegar na aldeia com transporte veicular.

$\mathrm{O}$ artesanato é tido como uma das atividades dos membros da aldeia, entretanto muitos trabalham na cidade, em instituições públicas ou privadas. O grupo de artesanato Mulheres indígenas é composto por nove mulheres, mas os homens da aldeia também produzem artesanato. Para os índios, culturalmente, a produção artesanal é uma atividade familiar. Os produtos são feitos à base de sementes da região e pena de animais, são feitos brincos, pulseiras e adereços para o cabelo pelas mulheres da aldeia, há ainda os cocás produzidos pelos homens. A comercialização é realizada de forma esporádica, em feiras ao qual são convidados a participar tanto no estado de Alagoas, como em todo Brasil e internacionalmente. Em contato com outras aldeias, fazem trocas de sementes e penas para a produção de novos produtos.

As artesãs da associação sentem falta de um ambiente de comercialização, já que na cidade em que residem não consegue vender seu artesanato. Os moradores da região desconhecem e não valorizam o artesanato indígena. Em outras ocasiões são questionadas se realmente são índias nativas, pois usam roupas comuns e compartilham de algumas características urbanas. Não atendendo as expectativas que são aprendidas culturalmente, ao qual os índios andam nus e enfeitados com penas.

Os índios da Serra do Capela praticam os princípios da economia solidária, a autogestão por exemplo é feita por eles de maneira consistente. De acordo com uma índia depois das capacitações sobre o que é economia solidaria, a tribo indígena apenas soube que as diretrizes usadas na aldeia faziam parte de uma outra forma de organização social e econômica que faz frente a um sistema tão desigual quanto o capitalismo. Uma outra índia 
quando questionada sobre os seus sonhos, responde que almeja um ambiente em que possa comercializar seu artesanato de forma livre.

\subsection{Microrregião da Serrana do Sertão Alagoano.}

Na mesorregião do Sertão Alagoano, estão ativos 30 sócios artesãos pertencentes a seis empreendimentos econômicos solidários (EES), sendo eles: Associação das Mulheres Quilombolas da Serra das Viúvas (AMAQUI) com 4 sócios (13\%), Associação Mulheres Mães Camponesas com 21 sócios (70\%) e Associação Renda Singeleza Nossa Senhora da Conceição com 5 sócios (17\%).

\section{Gráfico 5 - Sócios por empreendimento da Microrregião da Serrana do Sertão Alagoano}

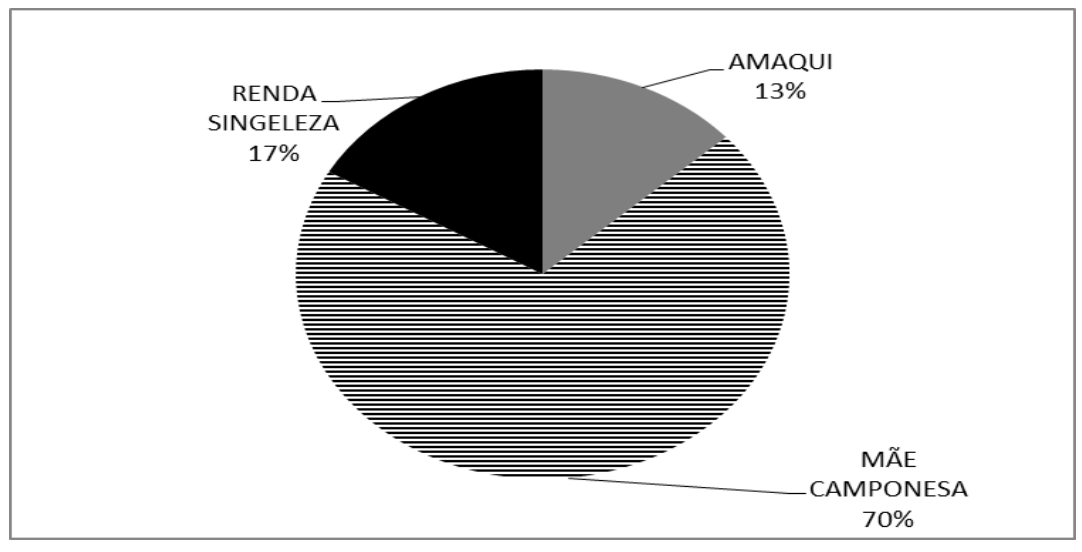

Fonte: Elaborado pelo autor

Os grupos estão instalados no município do Água Branca: AMAQUI que produz artesanato tipicamente quilombola, a base de cipó e palha de Licuri; Mulheres Mães Camponesas, que fazem pintura em tecido retratando a cultura do estado de Alagoas e a Associação Renda Singeleza Nossa Senhora da Conceição, que produz a renda delicada que é feita com agulha, linha e talos de coqueiros, sem necessitar risco ou moldes.

Os empreendimentos contêm na maior parte de sua formação mulheres, sendo $100 \%$ dos sócios da região do sexo feminino, dado que na cultura da região ainda reside o costume que o homem saia para trabalhar fora e a mulher fique em casa. 
Em relação ao nível de escolaridade dos sócios, pôde-se constatar que 37\% não chegaram a completar o ensino fundamental, tendo $13 \%$ o concluído, enquanto $30 \%$ completaram o ensino médio, somente 3\% conseguiram chegar ao nível superior de educação e 7\% não chegaram a ser alfabetizados. Referente a idade dos artesãos da região do sertão alagoano, 20\% tem idade entre 20 a 29 anos, 23\% entre 30 a 39 anos, 27\% entre 40 a 49 anos, $13 \%$ possuem entre 50 a 59 anos, $3 \%$ entre 60 a 69 anos, 3\% entre 70 e 79 anos e $10 \%$ não souberam ou optaram por não informar a idade.

Gráfico 6 - Faixa etária dos Sócios da microrregião da Serrana do Sertão Alagoano

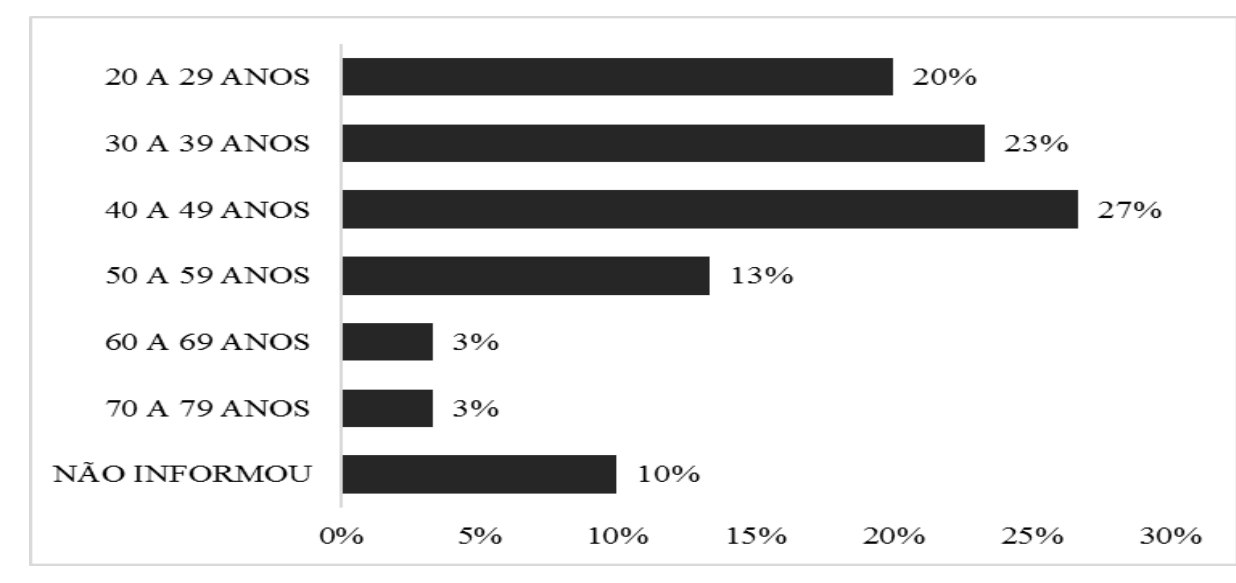

Fonte: elaborado pelos autores

Analisando o perfil dos artesãos da região, têm-se que $20 \%$ dos sócios tem o artesanato como profissão principal, já $80 \%$ possuem outras profissões como principais, dentre elas: professor, agente de endemias, secretaria e a mais citada é atividade agrícola. Deve-se considerar que $30 \%$ dos sócios moram em comunidades distante dos centros da cidade, em comunidades quilombolas ou periféricas, de difícil acesso, ao qual a principais atividades geradoras de renda são a agricultura de subsistência, a criação de gado e o artesanato.

A renda mensal obtida pelos sócios, individualmente, não ultrapassa três salários mínimos (SM), 45\% recebem até um SM, 5\% deles recebem de um a dois SM, 3\% tem renda mensal entre dois e três SM e $47 \%$ optaram por não informar o nível de renda recebido. Desses $33 \%$ recebem auxilio do bolsa família, enquanto $67 \%$ alegam não que não recebem o auxílio. 


\subsection{Microrregião da Serrana dos Quilombos}

Na Microrregião da Serrana dos Quilombos, no município de União dos Palmares está localizada a Associação de Artesãos de União dos Palmares (UNIART), o prédio em que os artesãos comercializam, que há 20 anos é cedido pela prefeitura. No momento o prédio encontra-se em reforma, que está sendo custeada pelos próprios artesãos.

O grupo está formado por 14 membros, sendo que somente nove deles estão ativos na produção. Quatro homens e quatro mulheres, que promovem uma produção diversificada, composta por palha de bananeira, bordado, madeiras e cabaças. Porém, há iniciativa de produção conjunta para direciona-la completamente para a palha da bananeira, afim de criar novos produtos como por exemplo: "um kit de praia" como eles o denominam.

Em relação ao nível de escolaridade dos sócios, pôde-se constatar que um sócio não chegou a completar o ensino fundamental, tendo dois que o concluiu, enquanto quatro sócios completaram o ensino médio, um que não concluiu e dois sócios conseguiram chegar ao nível superior.

\section{Gráfico 7 - Escolaridade dos Sócios da Microrregião Serrana dos Quilombos}

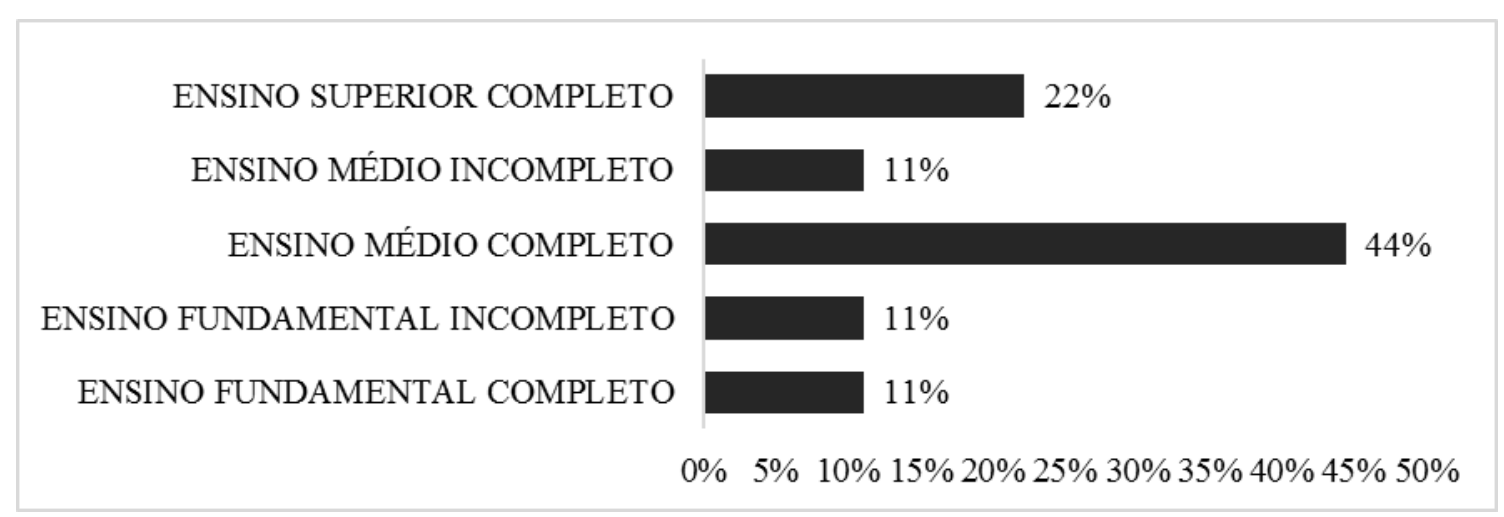

Fonte: elaborado pelos autores.

Referente a idade dos artesãos da região do sertão alagoano, $13 \%$ tem idade entre 20 a 29 anos, $25 \%$ entre 30 a 39 anos, $25 \%$ entre 40 a 49 anos, $13 \%$ possuem entre 50 a 59 anos e $25 \%$ entre 60 a 69 anos. 


\section{Gráfico 8 - Faixa Etária dos Sócios da Microrregião Serrana dos Quilombos}

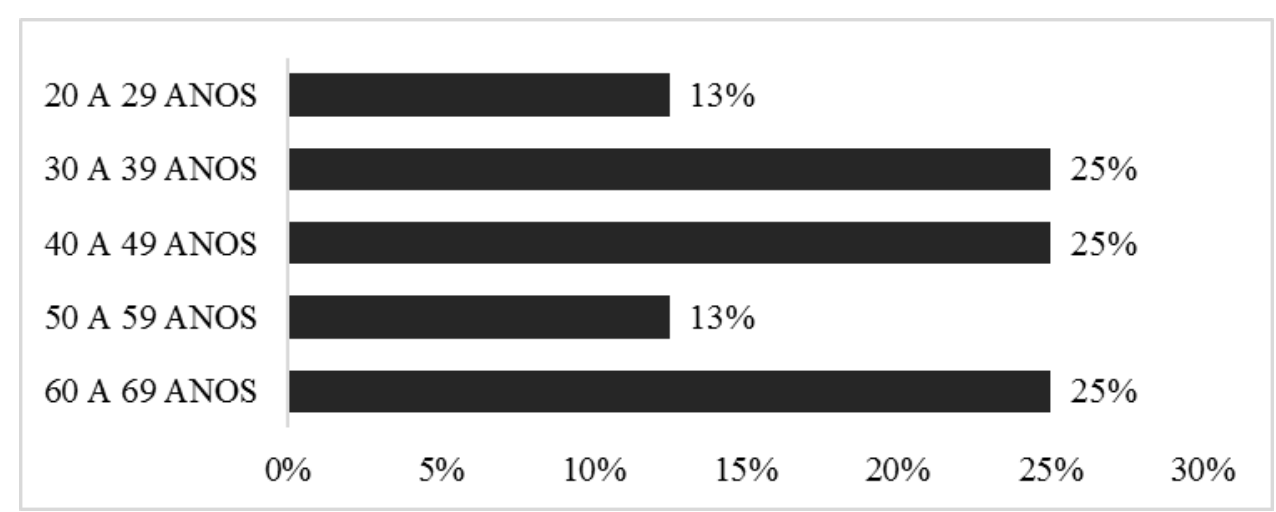

Fonte: elaborado pelos autores.

Analisando o perfil dos artesãos da região, têm-se que todos dos sócios tem o artesanato como profissão principal, afim de complementar a renda familiar. Seis sócios alegam não receber bolsa família e somente dois recebem o benefício. A associação tem a economia solidária e a produção artesanal enfraquecida, houve uma desunião entre os membros do grupo, tornando a participação dos membros vulneráveis a mudanças e saídas dos associados. Alguns acabaram deixando de produzir o artesanato e partiram para a revenda de produtos comprados em outras cidades.

\subsection{Microrregião Alagoana do Sertão do São Francisco.}

Na Microrregião Alagoana do Sertão de São Francisco, estão ativos 28 sócios artesãos pertencentes a seis empreendimentos econômicos solidários (EES), sendo eles: Associação dos Artesãos de Delmiro Gouveia (ART’DEL) com 7 sócios (12\%), Descanso do Rei com 13 sócios (22\%), Associação dos Artesãos Em Couro da Tilápia (Estação Cangaço) com 8 sócios (14\%). A Microrregião do Microrregião Alagoana do Sertão do São Francisco abrange três municípios do estado de Alagoas, os sócios supracitados pertencem a duas delas, sendo: 71\% de Delmiro Gouveia e 29\% de Piranhas. 


\section{Gráfico 9 - Sócios por Município na microrregião}

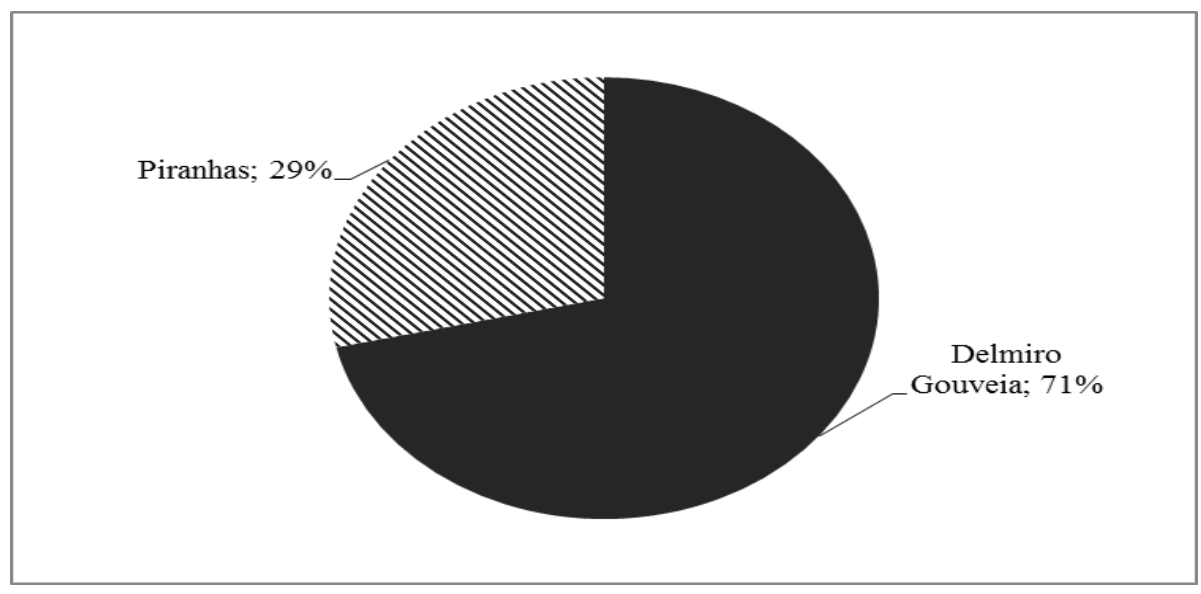

Fonte: elaborado pelos autores.

A Associação dos Artesãos em Couro da Tilápia, localizada na cidade de Piranhas, realiza seu artesanato a partir do couro de bode e tilápia, que antes eram descartados. Hoje esse material é reaproveitado e colocado no circuito produtivo através da produção de bolsas, cintos, calçados, carteiras, acessórios para a mulher e porta-moedas. O processo não leva produtos química e se transforma numa técnica autossustentável.

A Associação dos Artesãos de Delmiro Gouveia (ART'DEL) e o grupo Descanso do Rei estão lotados na cidade de Delmiro Gouveia, o primeiro produz artesanato com madeira, como pequenos objetos decorativos, também utilizam tecido para produzir carteiras, portamoedas e entre outros. O segundo tem suas peças feitas em tear que produz, a partir da linha, produtos com textura de rede, como descansos e jogos americanos. Os empreendimentos contêm na maior parte de sua formação mulheres, porém é possível observar uma maior participação nessa região de homens na produção do artesanato.

Em relação ao nível de escolaridade dos sócios, pôde-se constatar que $37 \%$ não chegaram a completar o ensino fundamental, tendo $13 \%$ o concluído, enquanto 30\% completaram o ensino médio, somente $3 \%$ conseguiram chegar ao nível superior de educação e 7\% não chegaram a ser alfabetizados. 


\section{Gráfico 10 - Nível de escolaridade dos sócios da microrregião}

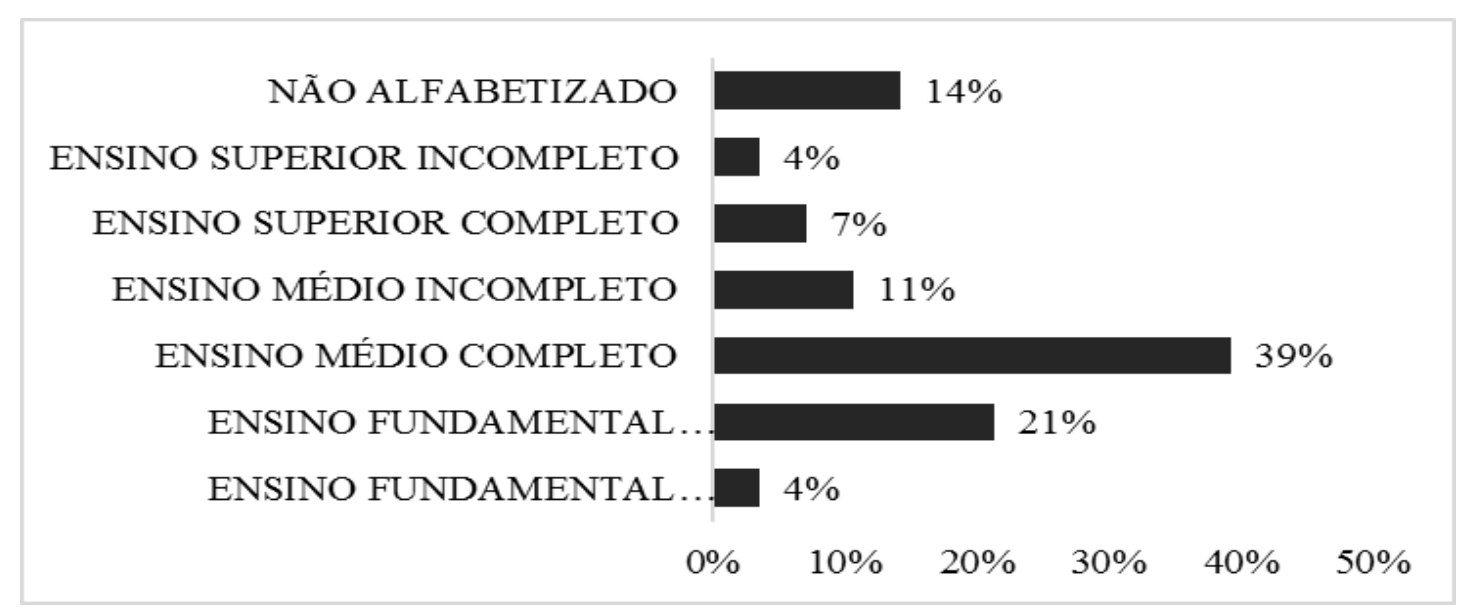

Fonte: elaborado pelos autores.

Referente a idade dos artesãos da região do sertão alagoano, $13 \%$ tem idade entre 20 a 29 anos, $25 \%$ entre 30 a 39 anos, $25 \%$ entre 40 a 49 anos, $13 \%$ possuem entre 50 a 59 anos e $25 \%$ entre 60 a 69 anos. Analisando o perfil dos artesãos da região, têm-se que todos dos sócios tem o artesanato como profissão principal, afim de complementar a renda familiar. Seis sócios alegam não receber bolsa família e somente dois recebem o benefício.

\section{Gráfico 11 - Principal profissão dos sócios da microrregião.}

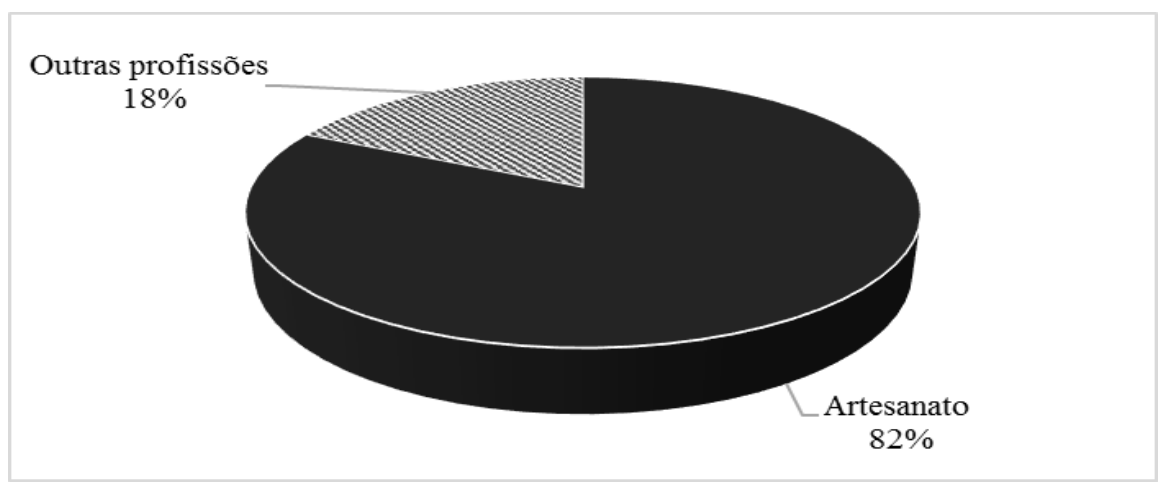

Fonte: elaborado pelos autores.

A associação tem a economia solidária e a produção artesanal enfraquecida, houve uma desunião entre os membros do grupo, tornando a participação dos membros variante. Alguns acabaram deixando de produzir o artesanato e partiram para a revenda de produtos comprados em outras cidades. 


\section{Considerações finais}

Esses experimentos sociais, para além de tecerem uma crítica empírica aos limites da produção da existência humana como capital, constroem como possibilidade - ainda que contraditória - uma nova práxis social que tem na solidariedade e na cooperação, novos nexos sociais. Buscam recuperar a centralidade do homem, suas habilidades produtivas e criativas resgatando em muitos dos casos a identidade cultural regional, unidos por laços de cooperação, ao invés da acumulação de capital como um fim em si mesmo. A produção coletiva se concretiza como uma proposta que propicia o desenvolvimento de relações sociais que tentam satisfazer necessidades sociais e materiais, recuperando os direitos dos trabalhadores. A lógica que se apresenta como impulsionadora dessas relações vem se manifestando como solidariedade, construindo ainda que embrionariamente um novo espaço social.

A unidade cooperativa como práxis solidária dá sustentáculo à reprodução dos Grupos, tendo nas habilidades criativas humanas a expressão de sua maior riqueza. A fragilidade desses Grupos relacionada com aspectos econômicos, como a falta de uma infraestrutura adequada, recursos, instalações, matérias-primas e outras que condicionam o desenvolvimento precarizando do grupo, desvelam a dificuldade de acesso aos meios de produção socialmente produtivos (os quais, nesta sociedade, são centralizados nas mãos de poucos capitalistas). Como acessá-los?

Como frisamos no início deste artigo, a marca do nosso tempo é a impossibilidade de muitos seres humanos produzirem a sua existência pelo capital. No início deste novo século, existe um conjunto de pessoas que já não conseguem mais ser nem assalariada, nem capitalista. Assim posta a problemática, a pesquisa que devemos empreender é para desvelar, de um lado, como os seres humanos alternativamente sobrevivem e, de outro, evidenciar que as formas sociais burguesas não mais possibilitam que todos vivam sob o seu manto, o que faz com que o desenvolvimento da sociedade, neste momento, seja a exclusão social e as consequências negativas daí advindas.

A humanidade está passando por um processo de transmutação da forma burguesa para uma nova forma de se produzir vida. Como todas as grandes transformações sociais, este caminho será longo e tortuoso. É possível que estejamos próximos da indignação pela destruição social da vida. Quando todos se unirem, não para produzir lucro ou salário, mas 
para produzir vida humana, é que estaremos muito próximos do tempo da emancipação humana (GRADE, 2006). Quando o homem alcançar sua emancipação plena, o resultado de sua produção consciente será o próprio homem. Só após este momento é que a humanidade terá dado seus primeiros passos como ser social pleno, pois todos serão responsáveis conscientemente pela vida de todos os seres humanos. 


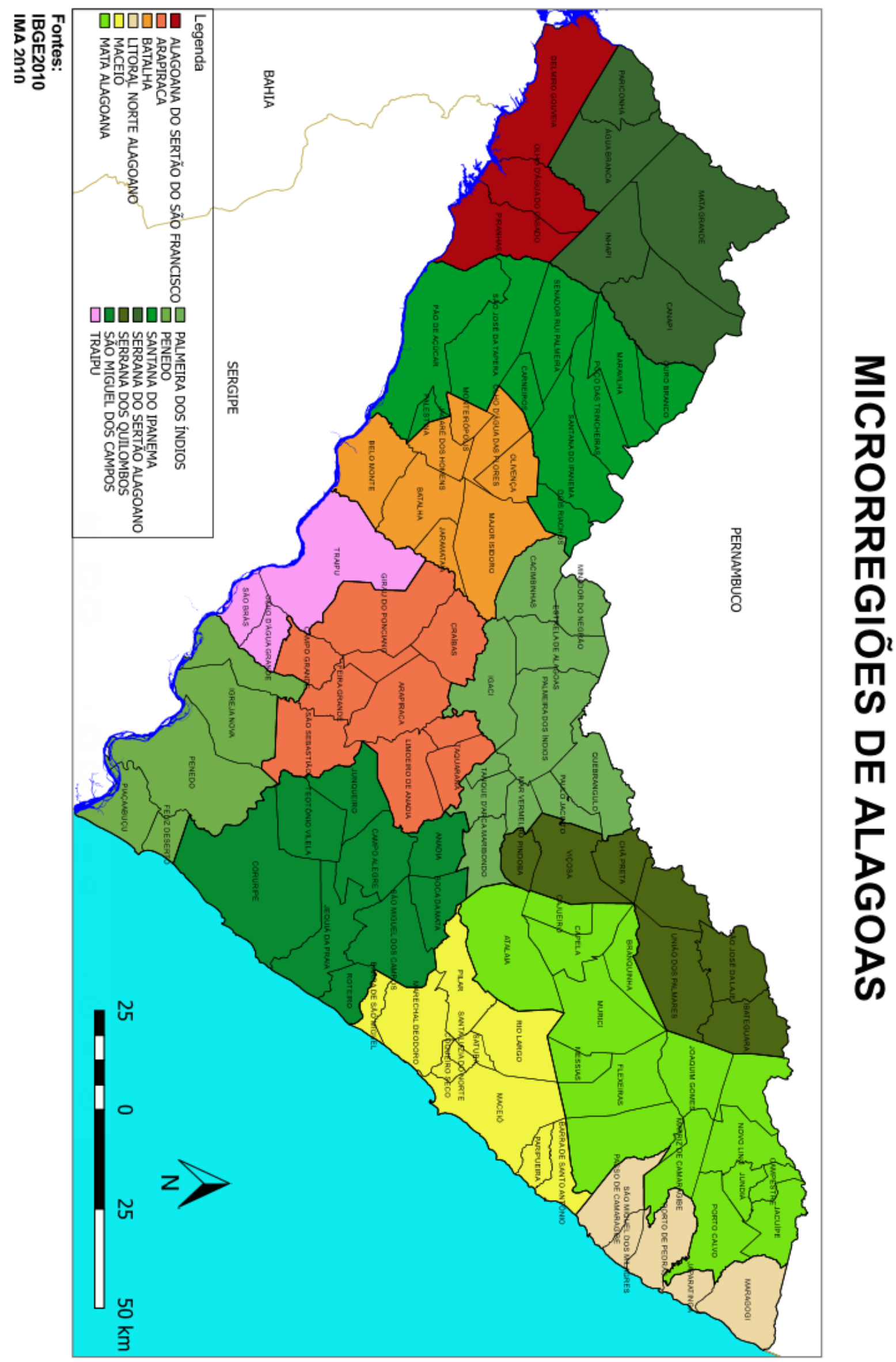




\section{Referências bibliográficas}

BETTELHEIM, Charles. A luta de classes na União Soviética. $2^{\mathrm{a}}$ ed., Paz e Terra: Rio de Janeiro, 1979.

CARR, E. H. A Revolução Russa de Lenin a Stalin (1917-1929). Zahar: Rio de Janeiro, 1981.

CASTELLS, Manuel. A sociedade em rede. São Paulo: Paz e Terra, 1999.

CHANIAL, Philippe \& LAVILLE, Jean-Louis. "Associativismo", in A. Cattani et al. (orgs.), Dicionário internacional da outra economia, Coimbra, Almedina, 2009, pp. 21-25.

COHEN, Stephen F. (1976). Bujarin y la revolución bolchevique. Siglo Veintiuno: Buenos Aires.

CULTI, M..O cooperativismo popular no Brasil: importância e representatividade. Disponível em: <http://www.ecosol.com. br/publicacoes> Acesso em: maio 2018.

CUNHA, G. C. A economia solidária e os embates em torno dos sentidos do cooperativismo na construção recente de leis e políticas. Bahia Análise \& Dados, Salvador: SEI, v. 23, n. 1, jan./mar. 2013. P.187-207.

DEFOURNY, Jacques. (1988), "Coopératives de production et entreprises autogérées: une synthèse du débat sur les effets économiques de la participation". Mondes en Développement, XVI (61): 139-53.

GAIGER, L. I. A economia solidária e a revitalização do paradigma cooperativo. Revista Brasileira de Ciências Sociais. V. 28, n. 82., jun. 2013. P. 211-259.

GAIGER. Luiz I. (org). Sentidos e experiências da economia solidária no Brasil. Porto Alegre, Editora da UFRGS, 2004.

GRADE, Marlene. Fórum do Maciço do Morro da Cruz e AGRECO como espaço transitório: germinando a espacialização de relações solidárias em Santa Catarina. Universidade Federal de Santa Catarina, Programa de Pós-Graduação em Geografia Doutorado, 2006.

GUERRA, Pablo. Socioeconomia de la solidaridad. Montevidéu, Nordan - Comunidad, 2002.

NAMORADO, R. Cooperativismo: história e horizontes. Estudos de Direito Cooperativo e Cidadania. V. 1. Coimbra, 2007. P. 9-35.

PINTO, João. Economia solidária: de volta à arte da associação. Porto Alegre, Editora da UFRGS, 2006.

SINGER, Paul. "A recente ressurreição da economia solidária no Brasil”, in B. S. Santos, Produzir para viver: os caminhos da produção não capitalista, Rio de Janeiro, Civilização Brasileira, 2002, pp. 81-130.

Recebido em 10 de setembro de 2018.

Aceito em 01 de novembro de 2018. 